\title{
SISTEM INFORMASI PEMILIHAN PEGAWAI PENERIMA PENGHARGAAN SATYA LENCANA KARYA SATYA DI RADIO REPUBLIK INDONESIA PALANGKA RAYA
}

\author{
Enny Dwi Oktaviyani ${ }^{\mathrm{a}, 1, *}$, Licantik $^{\mathrm{b}, 2}$, Loure Florentina ${ }^{\mathrm{c}, 3}$ \\ ${ }^{a}$ Jurusan Teknik Informatika FT UPR, J1 H. Timang Tunjung Nyaho \\ ${ }^{\mathrm{b}}$ Jurusan Teknik Informatika FT UPR, J1 H. Timang Tunjung Nyaho \\ ${ }^{\mathrm{c} J u r u s a n}$ Teknik Informatika FT UPR, Jl H. Timang Tunjung Nyaho \\ ${ }^{1}$ enny.obrien@gmail.com *; ${ }^{2}$ herbayuli_2005@yahoo.co.id; ${ }^{3}$ loureflo02@gmail.com
}

ARTICLE INFO

Keywords

Information systems website

Setya Lencana

Waterfall

$M y S Q L$

PHP

\begin{abstract}
Information system for selecting employee services receiving services in the radio of the republic of indonesia palangka raya aims to be a place of useful information provider for submission of award Satya lencana karya satya so that it could be effective, efficient, and accurate by simplifying the existing system. By having this website is expected to handle the process of logging employees so that it can help in the process of registration of a Nobel Prize Medal work of satya.

Methodology in the making of this website using the method waterfall, waterfall method which consists of several parts or stages - stages, namely analysis, design, coding and testing. This methodology was chosen because every step of the development of this website is structured, and clearly documented. The programming language used is PHP and MySQL as a database.

At this stage of testing this website using black box testing. After doing the testing, can be seen the result of this site that this website can perform its function, namely to manage data, time data family history, history of education, employment, lencan setya, data filing SKP, and PKP.
\end{abstract}

\section{Pendahuluan}

1.1 Latar Belakang

Penghargaan Satya Lencana Karya Satya bagi Pegawai Radio Republik Indonesia Palangkaraya dilaksanakan setahun sekali. dan hanya penghargaan Satya Lencana Karya Satya 20 tahun ke 30 tahun yang di selenggarakan di RRI Palangka Raya. Untuk mendapatkan penghargaan Satya Lencana Karya Satya, pegawai harus memenuhi syarat-syarat yang mengacu pada Peraturan Pemerintah Nomor 35 Tahun 2010 Pasal 22 yaitu Syarat khusus Tanda Kehormatan berupa Satyalancana Karya Satya adalah PNS yang telah bekerja dengan penuh kesetiaankepada Pancasila, Undang-Undang Dasar Negara Republik Indonesia Tahun 1945, negara dan pemerintah serta dengan penuh pengabdian, kejujuran, kecakapan, dan disiplin secara terus-menerus paling singkat 10 (sepuluh) tahun, 20 (dua puluh) tahun, atau 30 (tiga puluh) tahun, dengan ketentuan dalam masa bekerja secara terusmenerus, PNS yang bersangkutan tidak pernah dijatuhi hukuman disiplin tingkat sedang atau berat berdasarkan 
peraturan perundang-undangan atau yang tidak pernah mengambil cuti di luar tanggungan Negara.

Kepala bagian SDM sering kali mendapatkan kendala dalam pencarian data pegawai karena penyimpanan data di RRI Palangka Raya masih manual sehingga mempersulit dalam mengakses data yang disimpan. Jumlah data pegawai yang banyak dan sering berubah-ubah setiap bulannya, maka sangat sulit mengatur data pegawai yang dapat mengajukan Satya Lencana Karya Satya.

\subsection{Manfaat Penelitian}

Manfaat penelitian yang diperoleh dari Sistem Informasi Pemilihan Pegawai Penerima Penghargaan Satya Lencana Karya Satya Pada Rri Palangka Raya yaitu mempermudah proses pengajuan Satya Lencana Karya Satya bagi pegawai dan memberikan informasi kepada Kepala SDM siapa saja pegawai yg dapat mengajukan Satya Lencana Karya Satya di RRI Palangka raya

\subsection{Landasan Teori}

1. Website

Perkembangan internet yang sangat pesat telah membuat dunia baru, yang sering di sebut dengan dunia maya. Melalui dunia maya kita dapat melakukan banyak hal layaknya dunia nyata. Dengan berkembangnya dunia maya maka berkembang pula website, penggunaan website saat ini banyak diminati karena website dapat menyediakan semua yang dibutuhkan, mulai dari akses yang mudah, jangkauan yang tidak terbatas.

2. Penghargaan Satya Lencana Karya Satya

Penghargaan Satya Lencana Karya Satya bagi Pegawai RRI Palangkaraya dilaksanakan setahun sekali . dan hanya penghargaan Satya Lencana Karya Sartya 20 tahun ke 30 tahun yang di selenggarakan di RRI Palangka Raya. Untuk mendapatkan penghargaan Satya Lencana Karya Satya, pegawai harus memenuhi syarat-syarat yang mengacu pada Peraturan Pemerintah Nomor 35 Tahun 2010 Pasal 22 yaitu Syarat khusus Tanda Kehormatan berupa Satyalancana Karya Satya adalah PNS yang telah bekerja dengan penuh kesetiaankepada Pancasila, Undang-Undang Dasar Negara Republik Indonesia Tahun 1945, negara dan pemerintah serta dengan penuh pengabdian, kejujuran, kecakapan, dan disiplin secara terus-menerus paling singkat 10 (sepuluh) tahun, 20 (dua puluh) tahun, atau 30 (tiga puluh) tahun, dengan ketentuan dalam masa bekerja secara terus-menerus, PNS yang bersangkutan tidak pernah dijatuhi hukuman disiplin tingkat sedang atau berat berdasarkan peraturan perundang-undangan atau yang tidak pernah mengambil cuti di luar tanggungan Negara. Kepala Bagian SDM RRI Palangkaraya akan mencari kandidat pegawai penerima satya lencana karya satya dan jika pegawai sudah memenuhi syarat maka akan diajukan ke Kepala RRI Palangkaraya untuk mendapatkan penghargaan Satya Lencana Karya Satya

3. MySQL

MySQL adalah sebuah perangkat lunak system manajemen basis data SQL (DBMS) yang multithread, dan multi-user. MySQL merupakan implementasi dari system manajemen basisdata relasional (RDBMS). MySQL dibuah oleh TcX dan telah dipercaya mengelola system dengan 40 buah database berisi 10.000 tabel dan 500 di antaranya memiliki 7 juta baris. Pada saat ini MySQL merupakan database server yang sangat terkenal di dunia, semua itu tak lain karena bahasa dasar yang digunakan untuk mengakses database yaitu SQL. Tujuan dari pemakaian SQL dalam menyelesaikan masalah yang berkaitan dengan database.

\section{Data Flow Diagram}

Data Flow Diagram atau yang disingkat DFD merupakan diagram yang menggambarkan alir data dalam suatu entitas ke sistem atau sistem ke entitas. DFD juga dapat diartikan sebagai 
teknik grafis yang menggambarkan alir data dan transformasi yang digunakan sebagai perjalanan data dari input atau masukan menuju keluaran atau output [3]

a. Diagram Kontexs (Context Diagram)

Menurut (Jogiyanto,2005) Pengertian diagram konteks adalah: "Sebuah diagram sederhana yang menggambarkan hubungan antara entity luar, masukan dan keluaran dari sistem. Diagram konteks dipresentasikan dengan lingkaran tunggal yang mewakili keseluruhan sistem." [3]

b. Entity Relationship Diagram (ERD)

Entity Relationship Diagram (ERD) adalah diagram yang menghubungkan antar entitas di dalam penyusunan/perancangan basis data. Tujuan dari Entity Relationship Diagram adalah untuk menunjukkan objek data dan relationship yang ada pada objek tersebut. [1]

c. $P H P$

PHP adalah singkatan dari PHP Hypertext Processor. PHP mengijinkan pengembangan untuk menempelkan kode didalam HTML dengan menggunakan bahasa yang sama, seperti Perl dan UNIX shells. Obejk sumber tersusun sebagai halaman HTML, tetapi dengan generasi konten dinamis yang programmatic. [9]

\section{MetodologiPenelitian}

Metode Pengembangan perangkat lunak yang digunakan adalah metode Waterfall [6]. Waterfall model adalah sebuah contoh dari proses perencanaan, di mana semua proses kegiatan harus terlebih dahulu direncanakan dan dijadwalkan. Gambar 1 menunjukkan model waterfall [6].

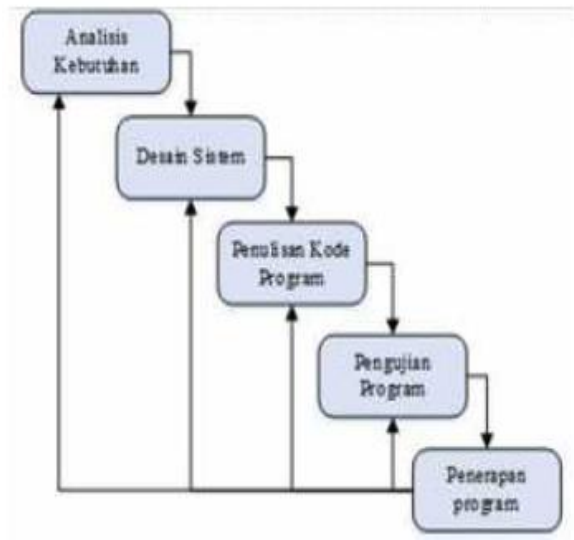

Gambar 1. Waterfall Model

1. Analisis Kebutuhan

Mengumpulkan kebutuhan secara lengkap, kemudian dianalisis. Didefinisikan kebutuhan yang harus dipenuhi oleh program yang akan dibangun. Analisis sistem ini meliputi :

a. Analisis Teknologi

b. Analisis Pengguna

c. Analisis Sistem lama yang sedang berjalan

d. Analisis Sistem baru yang diusulkan

2. Desain

Desain dikerjakan setelah kebutuhan selesai dikumpulkan secara lengkap. Proses perancangan sistem membagi persyaratan dalam sistem perangkat keras atau perangkat lunak. Menentukan arsitektur sistem secara keseluruhan. Dalam pembuatan Sistem ini, 
desain menggunakan DFD (Data Flow Diagram) terdiri dari Diagram Konteks, DFD Level 0, DFD Level 1, DFD Level 2, DFD Level 3 dan ERD (Entity Relationship Diagram).

3. Penulisan Kode

Desain program diterjemahkan kedalam kode-kode dengan menggunakan bahasa pemrograman yang sudah ditentukan. Program yang dibangun langsung diuji baik secara unit. Perancangan perangkat lunak direalisasikan sebagai serangkaian program atau unit program. Pengujian unit melibatkan verifikasi bahwa setiap unit telah memenuhi spesifikasinya. Dalam pembuatan sistem ini unit testing yang akan digunakan adalah black box testing.

4. Pengujian Program

Setelah pengkodean selesai maka akan dilakukan testing terhadap sistem yang telah dibuat. Tujuan testing adalah menemukan kesalahan-kesalahan pada sistem. Setelah pengujian sistem, perangkat lunak dikirim ke pengguna.

5. Penerapan dan Pemeliharaan Program

Tahap akhir dimana suatu perangkat lunak yang sudah selesai dapat mengalami perubahan - perubahan atau sesuai permintaan user.

\section{Hasil dan Pembahasan}

3.1. Analisis dan Desain

1. Analisis Sistem Lama

Kelemahan Sistem Lama

a. Kepala SDM sewaktu-waktu dapat teledor mengidentifikasi pegawai yang mendapatkan penghargaan Satya Lencana Karya Satya.

b. Pejabat Penilai memerlukan waktu lama menilai SKP pegawai

c. Kepala SDM membutuhkan waktu lama untuk mengidentifikasi pegawai yang mendapatkan penghargaan Satya Lencana Karya Satya karena syaratnya adalah pegawai tidak pernah menerima hukuman dan tidak pernah cuti diluar tanggungan negara dan SKP.

2. Analisis Sistem Baru Pengajuan Satya Lencana

Berdasarkan kelemahan sistem lama tersebut, maka muncul sebuah ide untuk membuat dan merancang sebuah sistem baru Sistem Informasi Kepegawaian (SIMPEG) Sebagai Penyedia Informasi Pemilihan Pegawai Penerima Penghargaan Satya Lencana Karya Satya Di RRI Palangka Raya yang berguna untuk memudahkan dan mengatasi kekurangan dari sistem sebelumnya

3. Proses bisnis SKP \& PKP

a. Mulai

b. Pegawai mengakses website

c. Sistem menampilkan halaman login

d. Pegawai menginput username \& password untuk login

e. Jika Username \& password benar maka sistem akan menampilkan Dashboard. Tetapi jika pegawai menginputkan username \& password salah maka akan kembali ke halaman login

f. Setelah berhasil login, Pegawai dapat melihat data, mengisi, mengedit data pegawai

g. Pegawai menginput target SKP

h. Kemudian Atasan mengisi SKP Pegawai dan merealisasi SKP \& PKP Pegawai kemudian sistem memproses SKP \& PKP dan menyimpan nilai SKP \& PKP pada database.

i. Setelah itu Admin dapat mencetak laporan pegawai, laporan SKP pegawai dan laporan PKP Pegawai. 


\section{JURNAL TEKNOLOGI INFORMASI}

[E-ISSN 2656-0321]

[Vol 13. No. 1]

j. Selesai

4. Analisis Sistem

a. Tahapan Analisa Pengguna.

Berguna untuk mengetahui siapa saja pengguna yang terlibat dalam website sistem informasi kepegawaian. Pengguna dalam sistem ini adalah admin, atasan, pegawai,

b. Tahapan Analisa Teknologi

Berguna untuk mengetahui tools atau aplikasi apa saja yang diperlukan dalam proses pembangunan website.

c. Tahapan Analisa Informasi

Berguna untuk mengetahui informasi dan data apa saja yang dapat didapatkan serta bermanfaat bagi pengguna ketika membuka dan website ini.

5. Desain Sistem

Pada bagian desain sistem ini berisi rancangan dasar program yang akan dibuat sesuai dengan sasaran awal program. Permodelan desain sistem ini dapat digambarkan dalam beberapa bagan, diantaranya adalah Diagram Arus Data (Data Flow Diagram) dan Bagan Relasi Entitas (Entity Relationship Diagram). Diagram konteks sistem ini dapat dilihat pada gambar 2.

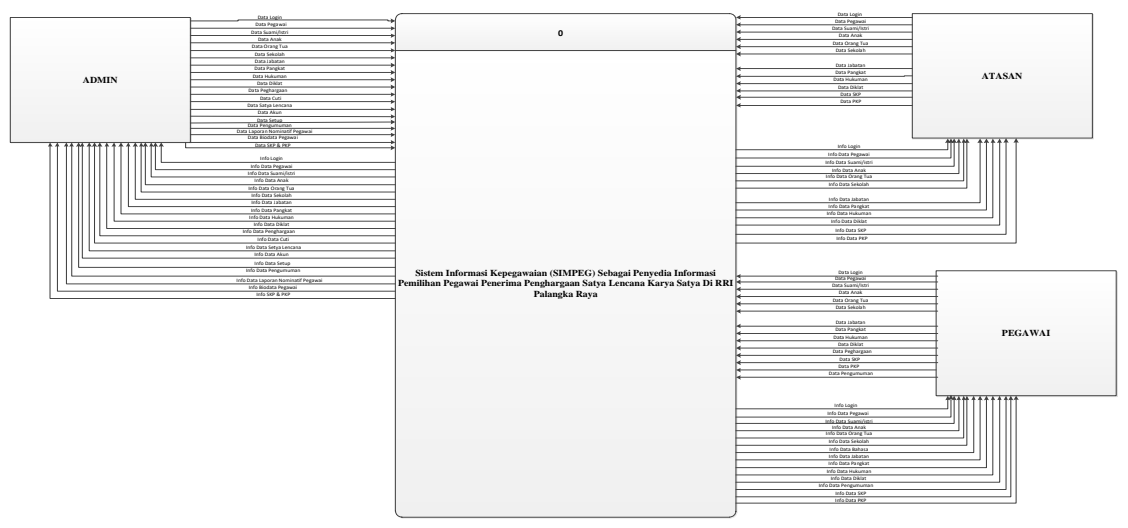

Gambar 2. Diagram Konteks

Entity Relationship Diagram (ERD) digunakan untuk membangun basis data untuk hubungan dari dua atau lebih entitas/tabel, gambar 3 menunjukkan Entity Relationship Diagram (ERD) 


\section{JURNAL TEKNOLOGI INFORMASI}

[E-ISSN 2656-0321]

[Vol 13. No. 1]

[Januari 2019]

\section{Jurnal Keilmuan dan Apjlikasi Bidang Teknik Informatika}

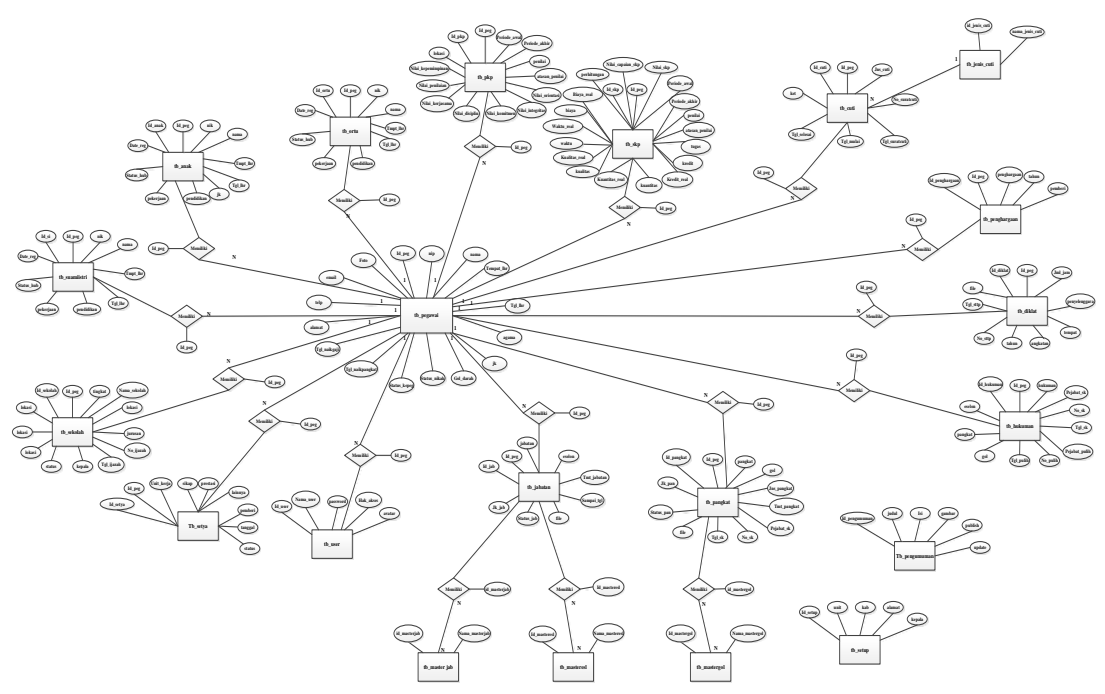

Gambar 3. ERD

6. Implementasi dan Pengujian

Setelah melewati tahap pengkodingan selanjutnya adalah tahap implementasi. Tahap implentasi dibagi menjadi empat bagian, yaitu implementasi data, implementasi proses , implementasi antarmuka dan pengujian perangkat lunak.

\subsection{Implementasi Proses}

Implementasi proses adalah pengembangan dari perancangan dan pemodelan sistem.

Proses-proses yang penting pada system informasi gaji adalah :

a. Admin atau Kepala Bagian SDM sebelumnya melakukan proses login dengan menginputkan username dan password apabila login berhasil admin akan masuk ke halaman utama kendali admin website. Admin memiliki hak akses untuk mengelola data yang digunakan dalam sistem informasi ini dan membuat akun bagi Atasan dan Pegawai.

b. Atasan sebelumnya melakukan proses login dengan menginputkan username dan password apabila login berhasil atasan akan masuk ke halaman utama pimpinan website. Atasan hanya dapat melihat Data Pegawai, Suami Istri, Anak, Orang Tua, Pendidikan, Bahasa, SKP, PKP, Pangkat, Jabatan, Hukuman Diklat, dan Penghargaan.

c. Pegawai yang telah dibuatkan akun oleh Admin sebelumnya dapat melakukan proses login dan apabila berhasil mendapatkan hak untuk melakukan pengelolaan data personalnya, suami istri, anak, orang tua, pendidikan, bahasa, SKP, PKP, Pangkat, Jabatan, Hukuman, Diklat dan Lihat Pengumuman

\subsection{Implementasi Rancangan Antarmuka ( Interface )}

Implementasi Login dapat terlihat pada gambar 4 berikut ini 


\section{JURNAL TEKNOLOGI INFORMASI}

[E-ISSN 2656-0321]

[Vol 13. No. 1]

Jurnal Keilmuan dan Aplikasi Bidang Teknik Informatika

[Januari 2019]

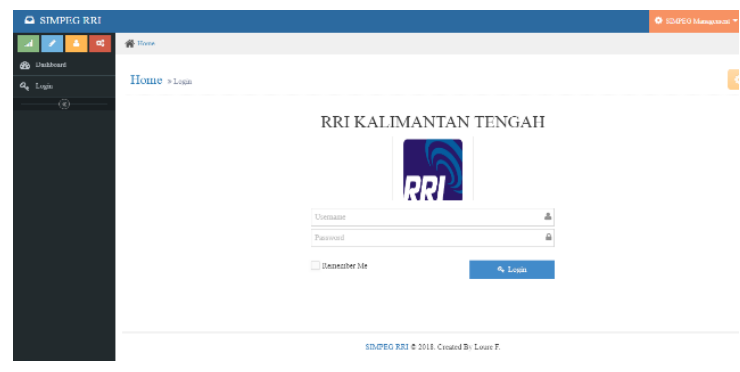

Gambar 4. Halaman Login

Implementasi Daftar Pegawai dilihat pada gambar 5 berikut ini.

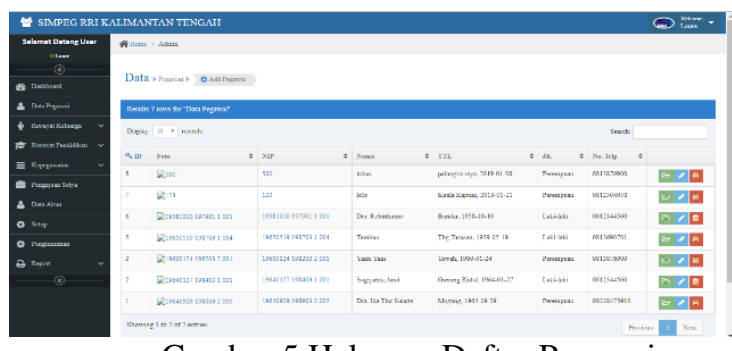

Gambar 5 Halaman Daftar Pegawai

Implementasi SKP dapat dilihat pada gambar 6 berikut ini.

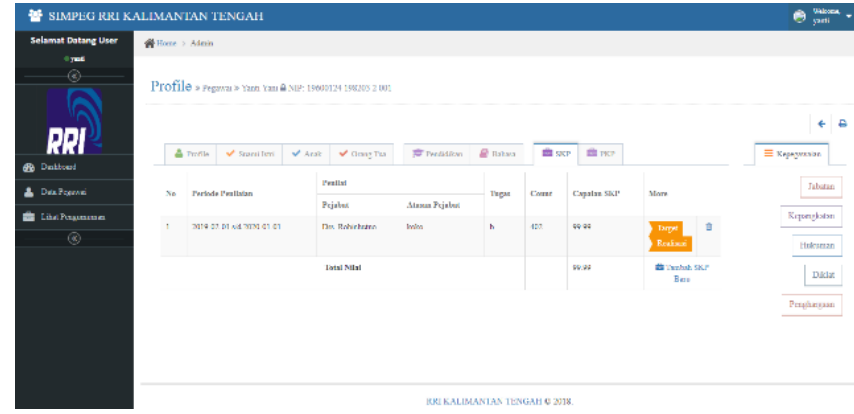

Gambar 6. Halaman SKP

Implementasi PKP dapat dilihat pada gambar 7 berikut ini.

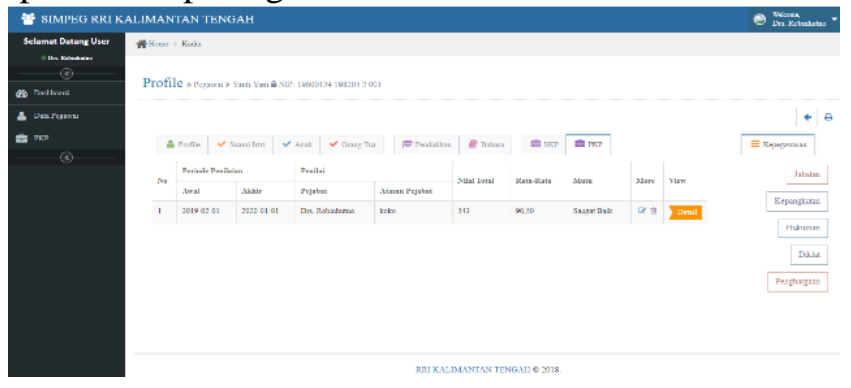

Gambar 7. Halaman PKP

Implementasi SKP \& PKP admin dapat dilihat pada gambar 8 berikut ini. 


\section{JURNAL TEKNOLOGI INFORMASI}

[E-ISSN 2656-0321]

[Vol 13. No. 1]

Jurnal Keilmuan dan Aplikasi Bidang Teknik Informatika

[Januari 2019]

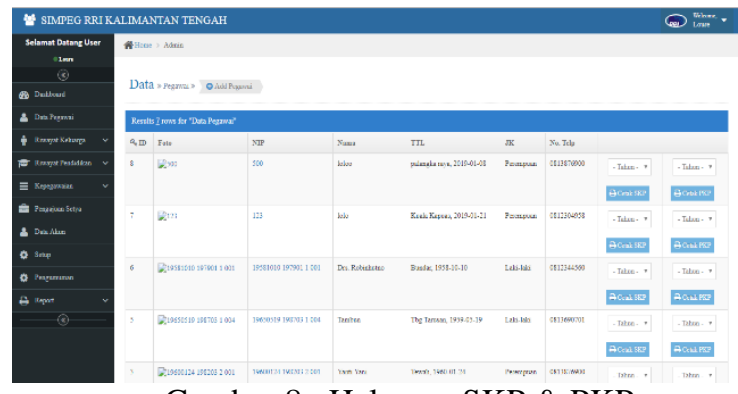

Gambar 8. Halaman SKP \& PKP

\subsection{Pengujian Perangkat Lunak}

Untuk tahap Pengujian Perangkat Lunak metode yang digunakan adalah Blackbox Testing. Blackbox testing adalah pengujian yang dilakukan oleh calon pengguna aplikasi yaitu pengujian oleh pengunjung untuk membuktikan bahwa Sistem Informasi Pengajuan Setya Lencana yang dibuat telah berfungsi dengan baik dan untuk mengetahui kebenaran fungsi dan alur program

\section{Kesimpulan}

Berdasarkan hasil pengujian, maka sistem Informasi pemilihan pegawai penerima penghargaan satya lencana karya satya di RRI Palangka Raya dapat digunakan sebagai tempat penyedia informasi yang berguna untuk pengajuan mendapatkan penghargaan satya lencana karya satya sehingga dapat menjadi efektif, efisien, serta akurat dengan menyederhanakan sistem yang ada.

Untuk penelitian selanjutnya dapat menambah simulasi cuti dan hukuman di fitur pengajuan satya lencana yang dapat berguna bagi Kepala SDM (admin), Pegawai maupun Kepala RRI

\section{Daftar Pustaka}

[1] Fathansyah. 2012. Basis Data. Bandung: Informatika

[2] Jogiyanto. 2012. Pengantar Sistem Informasi. Yogyakarta : Andi

[3] Jogiyanto HM. 2005. Analisis dan Desain: Sistem Informasi Pendekatan Terstruktur Teori dan Praktik Aplikasi Bisnis. Penerbit: Andi Offset, Yogyakarta.

[4] Kadir, Abdul. Pengenalan Sistem Informasi. Yogyakarta : Andi

[5] Kustiyahningsih, Yeni. 2011. Pemrograman Basis Data Berbasis Web Menggunakan PHP dan MySQL. Yogyakarta : Penerbit Graha Ilmu.

[6] Sommerville, Ian. 2011. Software Engineering (Rekayasa Perangkat Lunak). Jakarta : Erlangga.

[7] Sutabri, Tata. 2012. Analisis Sistem Informasi. Yogyakarta:Andi

[8] Sutarman.2012.Pengantar Sistem Informasi.Jakarta:Bumi Aksara.

[9] Peranginangin, Kasiman. 2009. Aplikasi web dengan PHP dan MySql. Yogyakarta. Penerbit: Andi Offset.

[10] Rosario, Alexander.F.K. 2013. Web Programming Power Pack. Yogyakarta. Penerbit: MediaKom. 
[11] Pressman, Roger S., 2002, Rekayasa Perangkat Lunak: Pendekatan Praktisi jilid Dua, Penerbit: Andi Offset, Yogyakarta 